\title{
How to Trace out Impact-Triggered Effects Globally Scattered around Formation Boundaries: Case Uhry, North Germany (Eocene/Oligocene Boundary)
}

\author{
Werner Schneider ${ }^{1}$, Elias Salameh ${ }^{2}$ \\ ${ }^{1}$ Emeritus: University of Braunschweig, Braunschweig, Germany \\ ${ }^{2}$ University of Jordan, Amman, Jordan \\ Email: salameli@ju.edu.jo
}

How to cite this paper: Schneider, W. and Salameh, E. (2018) How to Trace out Impact-Triggered Effects Globally Scattered around Formation Boundaries: Case Uhry, North Germany (Eocene/Oligocene Boundary). Open Journal of Geology, 8, 9-32. https://doi.org/10.4236/ojg.2018.81002

Received: November 16, 2017

Accepted: January 12, 2018

Published: January 15, 2018

Copyright ( 2018 by authors and Scientific Research Publishing Inc. This work is licensed under the Creative Commons Attribution International License (CC BY 4.0).

http://creativecommons.org/licenses/by/4.0/

\begin{abstract}
By focusing on impact-triggered phenomena having occurred synchronously with or shortly prior to formation boundaries, two glass sand pits (Upper Maastrichtian) located near Uhry, North Germany have been studied in regard to the K/T boundary throughout the last 40 years during progressive exploitation of glass sand. However, a clastic sequence of sand, mass flow and pelite deposited in a deep channel of about $10-12 \mathrm{~m}$ in depth, eroded into the glass sand, surprisingly shows an Upper Eocene/Lower Oligocene age, well defined by a Dinocyst assemblage (Chiripteridium c. galea, Enneado cysta arcuata, Areoligera tauloma $=$ D 12na - D 14na) from a 0.5 meter thick pelite that marks the Rupelian transgression within an estuarian system running northwest/southeastward. The section exposes a high energy mass flow and formerly solid frozen angular glass sand blocks of up to a meter-size embedded in fluvial sand of the channel base. Furthermore, erratic clastics of up to 0.4 meter in diameter appear at the pelite base. The "unusual" Dinocyst assemblage is of autochthonous origin and comprises the fresh water alga Pediastrum Kawraiskyias indicator for cold climate, hitherto only known from Quaternary. Missing pollen indicate a vegetation-less hinterland. Thus, there cannot be any doubt that around the E/O b. at least one "rare event" has happened as verified by short tremendous flooding and significant temperature fall ("cosmic winter"). According to the attitude of the global impact scientific community, these phenomena belong to the spectrum of "indirect effects" of major impacts. Radiometric ages of relevant major impact events underline that both impact craters of Popigai, Russia (100 Kilometer in diameter, 35.7 $\mathrm{Ma}$ ) and Chesabreake, USA (85 Kilometer in diameter, $35.5 \mathrm{Ma}$ ) happened
\end{abstract}


shortly before the E/O b. $(33.75 \mathrm{Ma})$. In addition, a tektite strewn field along the eastern coast of the USA and micro-tektites (Gulf of Mexico, Caribbean Sea, Barbados) yield an age of $\sim 34.4 \mathrm{Ma}$, close to the E/O b. Consequently, there does exist an extremely high probability that Uhry site hosts impact-triggered products at the E/O b. It should be stressed that the Upper Eocene Epoch comprises an amazingly high number of impact events during the time-span 34.2 - 37.0 Ma.

\section{Keywords}

Impact-Triggered, Eocene/Oligocene Boundary

\section{Introduction}

This paper follows the spirit of both following quotations:

"Since merely effects are accepted on the screen of science, it seems to be constrained to trace something quite scarce and remote if we search for "indirect effects". The trick of science insists on to admit the proof only in form of logical pointing out that means in the horizon of a "series of effects". Then, "indirect effects" can certainly never be proved, and the forecast "indirect effects" would not exist, owns the form of self-fulfilling prophecy.

A.M.K Müller [1], (transl. Sch.)

"The recognition of the sedimentologic consequences of "Convulsive Events" ("Rare Events") poses a special challenge to sedimentary geologists. Meeting this challenge will almost certainly demonstrate that "Convulsive Geologic Events" have greater relevance to the sedimentary record than has been previously recognized.

H. E. Clifton [2].

Since the discovery of the Chicxulub Impact Event, Yucatan, Mexico (K/T) [3], there does exist a general acceptance among the majority of the scientific community of globally scattered major impact-triggered phenomena, as listed up below:

- Iridium-enriched soot-bearing kaolinite boundary clay [4] [5] [6]

- Wildfires, whirlstorms [4] [5] [6] [7]

- Tektites and microtektites [8]

- Tremendous heavy rainfall and flooding [9] [10] [11] under strong influence of nitric and other acids [12] [13] [14] originating kaolinite [5] and mass flow deposits [15] [16] [17] [18]

- Sintwinter (Cosmic Winter) throughout years, even hundreds of years preventing photosynthesis [19]

- Environmental pollution by acids, gases, and heavy metals initiating, in connection with missing photosynthesis, mass extinction [14] [20] [21] [22] 
- Triggering of faulting, volcanism, earthquakes, salt diapirism, tsunamis, activation of tectonic nappes, with influence on plate tectonics at all [2] [23] [24].

For synopsis and discussion of this evidence spectrum see [10] [18] [19] [24] [25].

Impact sites of relevance for this paper are the meteorite craters of Chicxulub, Yucatan, Mexico (200 Km ø, $65 \mathrm{Ma}$ ) and both Popigai, Russia (100 Km ø, 35.7 $\mathrm{Ma}$ ), and Cheasabreake, Maryland, Virginia, USA (5 Km ø, $35.5 \mathrm{Ma}$ ), [23] [26]. Thus, concerned here are the Cretaceous/Tertiary (K/T) boundary and the Eocene/Oligocene boundary.

For checking some of the parameters listed above, two glass sand pits located atUhry Village near Braunschweig, North Germany have been studied throughout the last 25 years during the continuous sand/gravel exploitation for glass industries (Figure 1(a), [27]).

Both pits (Schlingmeier, Ewers) expose Maastrichtian glass sand and Upper Eocene/Lower Oligocene clastics, comprising several unconformities, all overlain with Pleistocene moraine and fluvio-glacial deposits (Figure 2(a) and Figure 2(b), Latitude 5797500, Longitude 4422600/4422160).

\section{Geologic and Paleogeographic Setting}

The study area is located in a transitional zone of an estuary system whose clastics were transported from southeast/east, towards the open sea situated in a northwestern direction in the time period of Cretaceous through Lower Tertiary (Figure 3(a) and Figure 3(b) [28]). Uh Uhry.

The horse shoe-like arranged huge hinterland/source area comprised the peneplained Variscan Basement and its Mesozoic overburden of Middle Germany [29], the Elbe zone [30], the Harz Mts. [29], the Flechtingen Ridge [29], and the exhumed transpressional structure of the Aller Valley zone [31].

Both pits are subjected to exploitation of kaolinite-bearing Maastrichtian glass sand deposited within both rim synclines of the Beienrode salt Diapir/Dorm Structure (Figure 1(b) and Figure 1(c), [32] [33] [34]). However, the salt ascent started fairly and abruptly around the K/T b. and continued through Paleocene [27]. So the glass sand originally covered the (later) diapir.

Lower Eocene pelite, not deposited in the pits investigated, but exposed $\sim 2$ kilometers west of them (open Parseier pit P), discordantly $\left(20^{\circ}-25^{\circ}\right)$ overlies the glass sand which indicates the end of diapirism around the Paleocene/Eocene b. [27].

The glass sand pits exhibit an up to 12 meters deep flat channel eroded into the glass sand (Figure 4). Its fill exposes coarse-grained, well-sorted fluvial sand overlain with a mass flow (fanglomerate) up to 2 meters thick, hitherto unknown (Figure 5).

The latter is preserved as channel relics but had originally a larger extension, [35]. Its pebble assemblage totally differs from that of the Pleistocene of the northern provenance. 


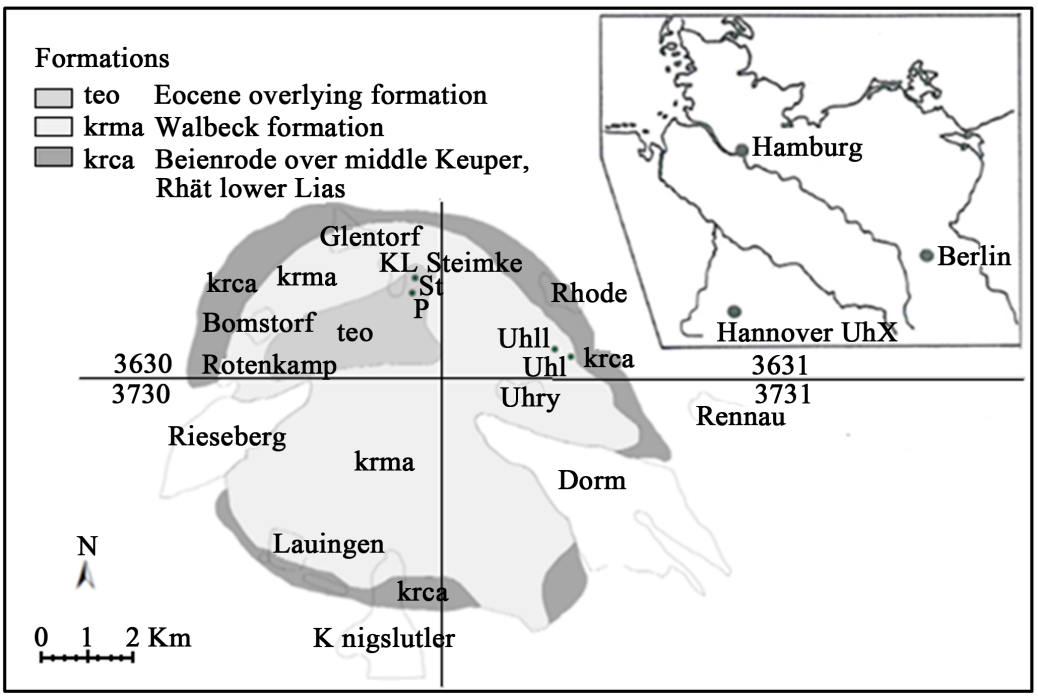

(a)

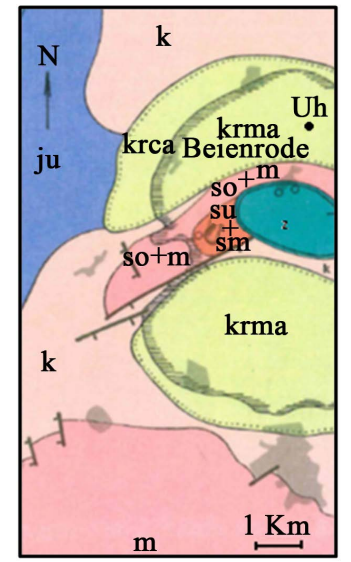

(b)

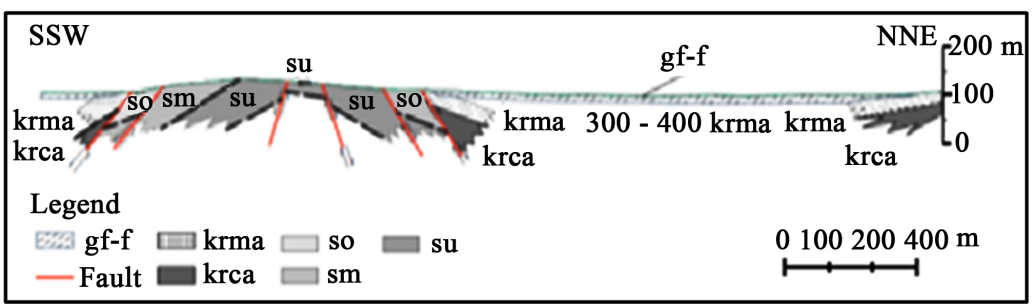

(c)

Figure 1. Geologic position of the study area at Uhry. TK 3631 Gr. Twülpstedt. (a) Location of the Beienrode Basin and the Beienrode/Dorm Salt Structure showing the site of Maastrichtian glass sand pits (Uh I: Schlingmeier, Uh II: Ewers), northeast of the Uhry Village, and Lower Eocene outcrops at Klein-Steimke (St. I) and the Parseierpelite pit (p). krca Campanian, krma Maastrichtian, teo Eocene; modified from [27]; (b) Beienrode Salt Diapir (z) accompanied by its rim synclines (krca, krma). Location of both glass sand pits (Uh) within the northern rim syncline. $z$ Upper Permian (Zechstein), su, sm, so Lower Triassic (Buntsandstein), m Middle Triassic (Muschelkalk), k Upper Triassic (Keuper), ju Jurassic, krcaCampanian, krmaMaastrichtian, without Cenozoic overburden. Modified from [32]; (c) cross-section of the Dorm Anticline east of the diapir (b). Note the post-Masstrichtian diapirism and the glass sand deposition (krma) across the structure. su, sm, so Lower Triassic, krca Campanian, gf-f Pleistocene (after [33] [34]). 


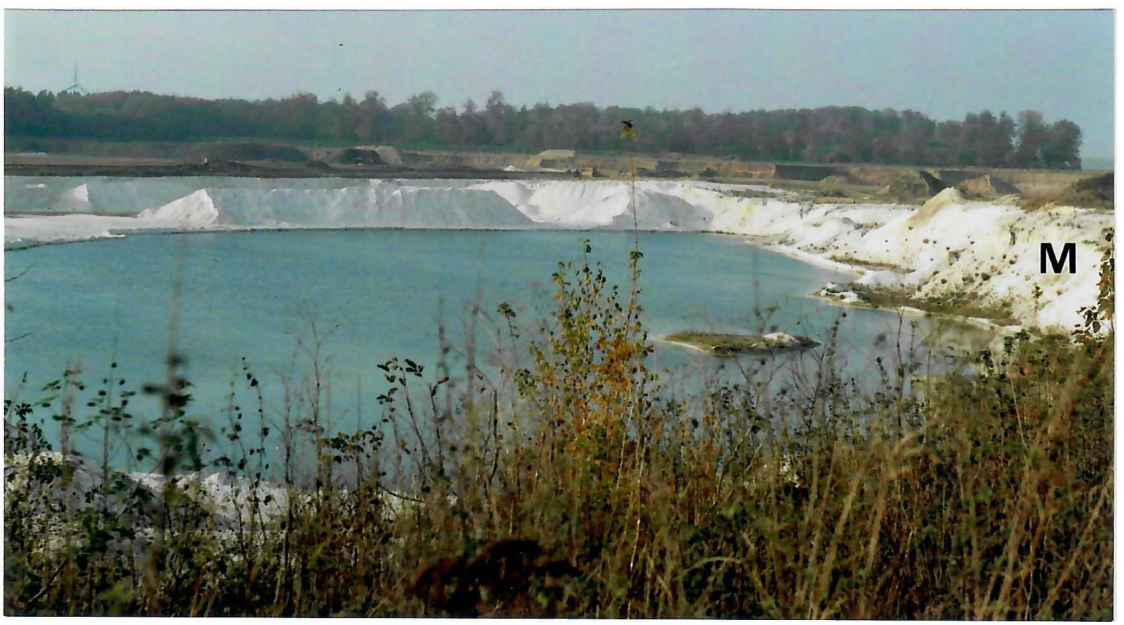

(a)

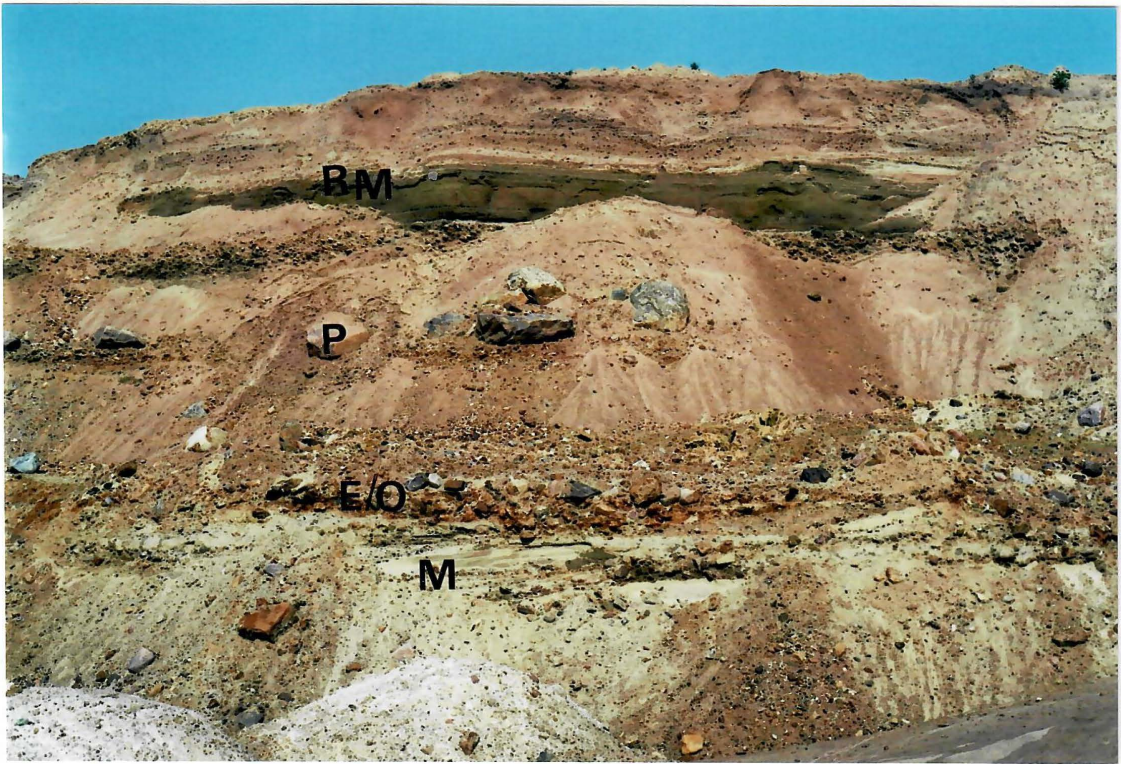

(b)

Figure 2. General overview of the Ewers glass sand pit (Uh II). (a) Maastrichtian glass sand (white) in the northern rim syncline (M) overlain with Pleistocene deposits (brown); (b) well-bedded glass sand (M) overlain with Upper Eocene/Lower Oligocene mass flow (E/O) which is covered with Pleistocene fluvioglacial and moraine deposits (p) and reworked glass sand (RM).

The channel deposits are overlain with dark/grey-greenish pelite of Upper Eocene/ Lower Oligocene age, hitherto also unknown.

\section{Biostratigraphy and Major Impacts}

Biostratigraphy relates to Dinocyst assemblages of [36], is here faced with the concept of Price [23] that many formation b. coincide with major impacts ("Rare Events") affecting Plate Tectonics throughout Earth History [37]. Figure 6 summarizes the biostratigraphic and major impact data, for the relevant time span. 


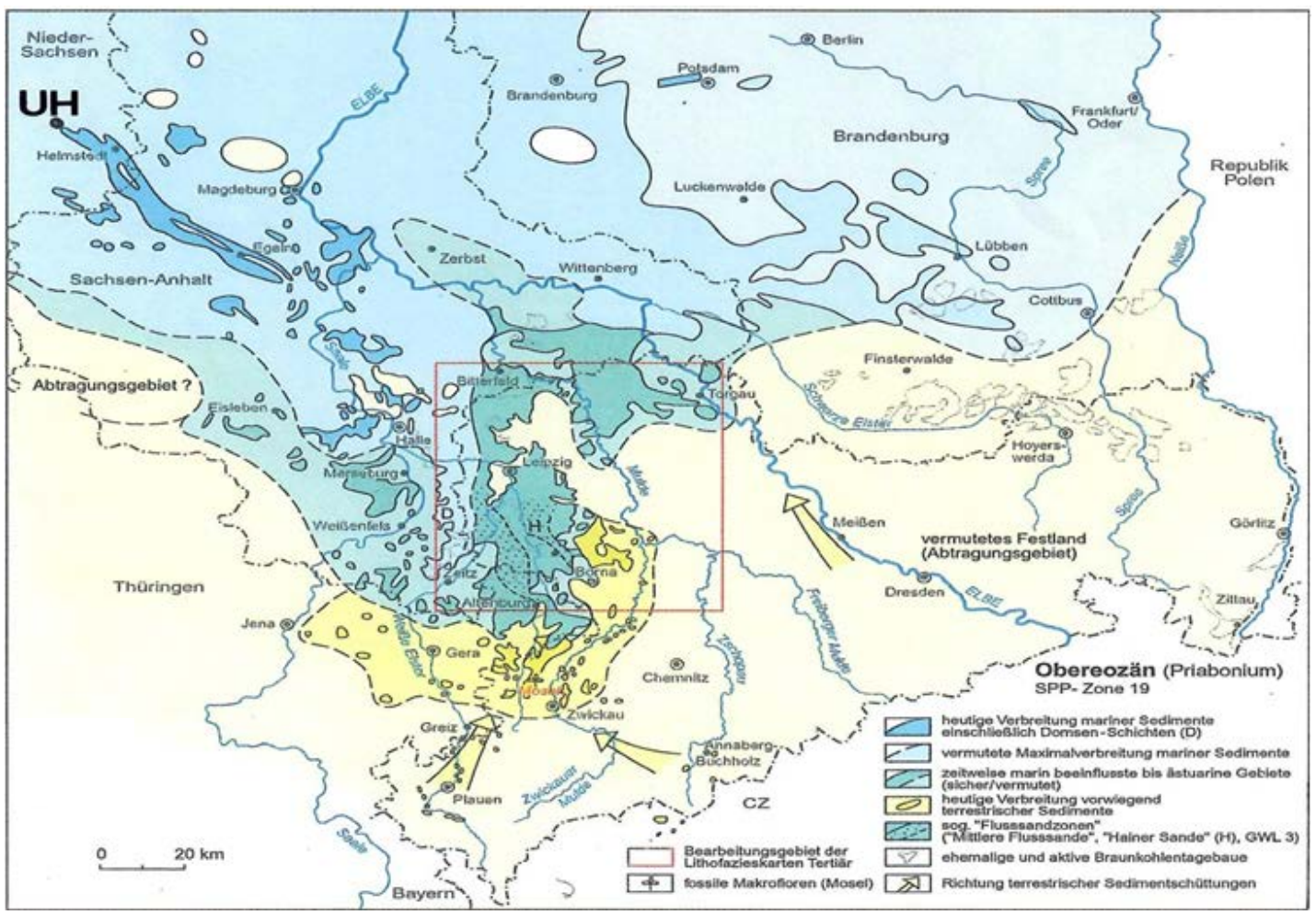

(a)

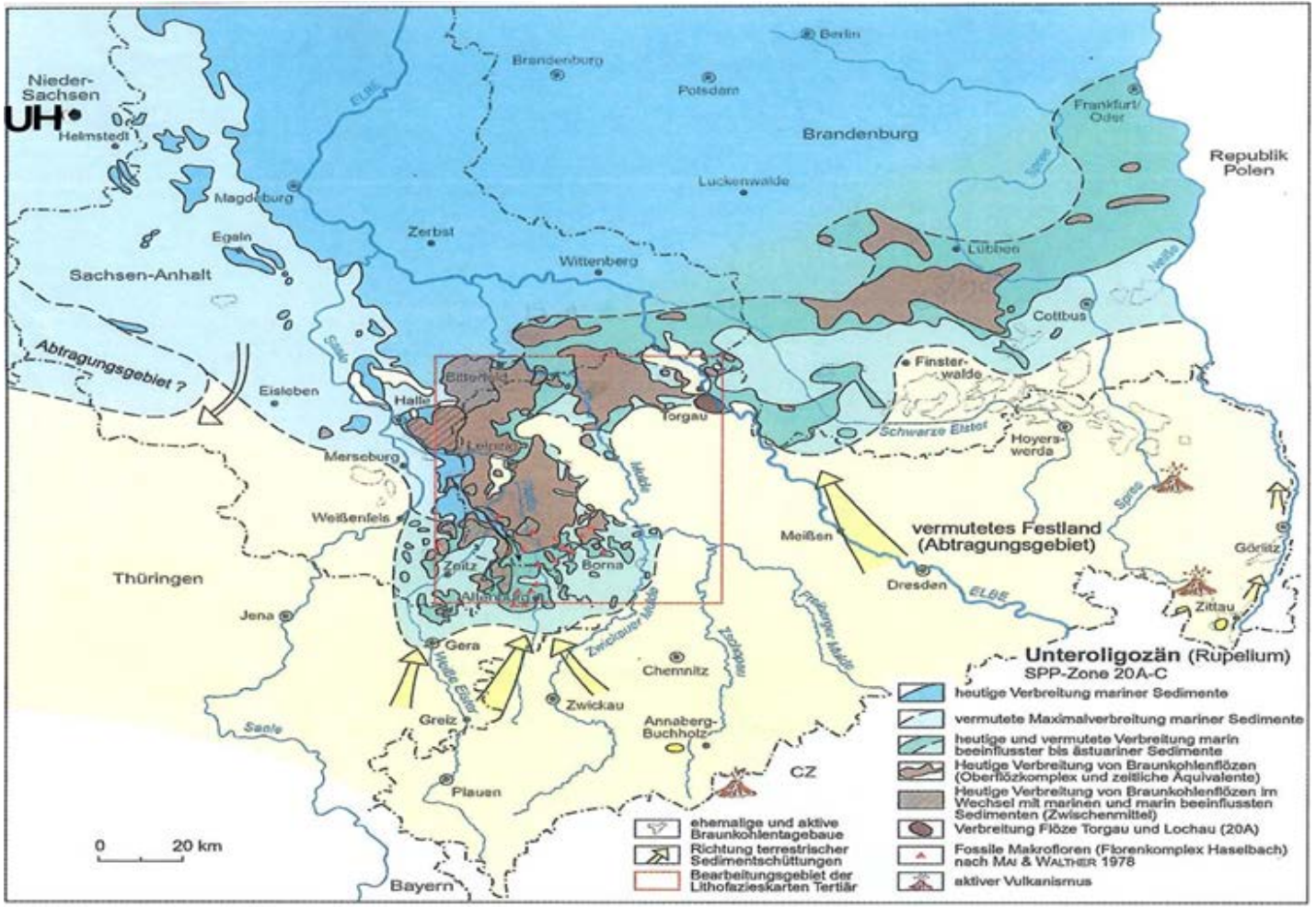

(b)

Figure 3. Paleogeographic situation through the late Upper Eocene ((a) Priabonian, SPP 19) and Early Oligocene ((b) Rupelian, SPP 20 A-C), [28]. Note the abrupt facies change by the Eocene/Oligocene transgression. The macroflora-bearing Haselbach Pelites may correlate with the boundary pelite at Uhry (see Figure 4.13). Uh I, II site. 


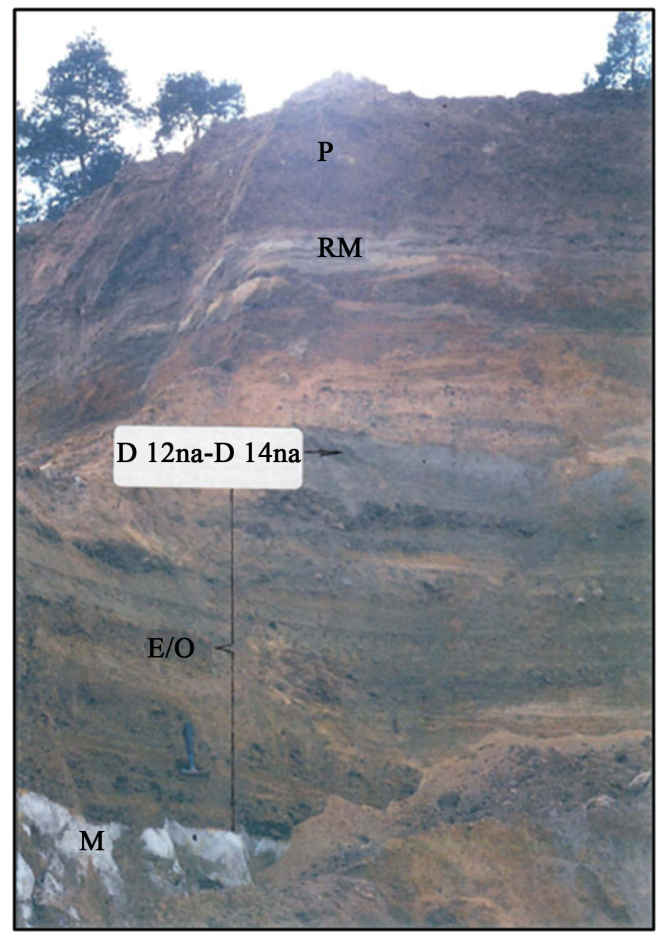

Figure 4. Former profile in the Schlingmeier pit (Uh I) during glass sand exploitation. Base: white glass sand (M) erosively overlain with fluvial clastics and mass flow (E/O). Greenish Upper Eocene/Lower Oligocene pelite (D 12 na - D 14 na: [36]) covered with Pleistocene deposits (P), the latter intercalated with reworked glass sand (RM).

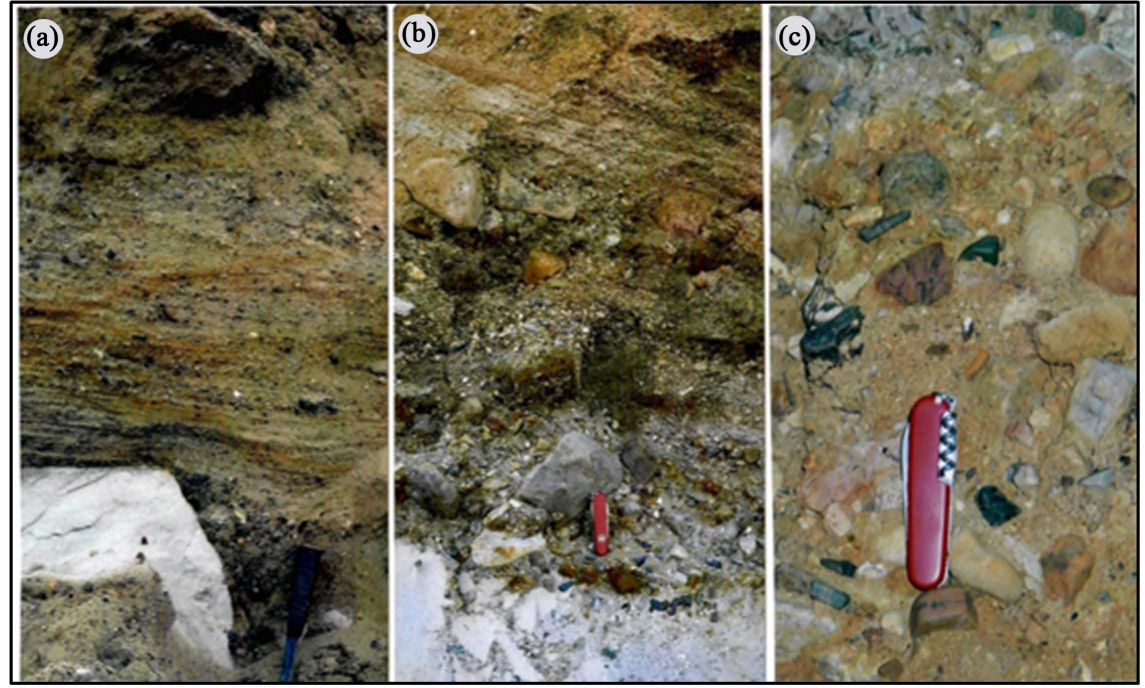

Figure 5. Basinal fluvial clastics and mass flow. (a) Basinal fluvial clastics (sh) in lateral and vertical erosional contact to the underlying Maastrichtian glass sand. As primary components of the glass sand friable white pebbles are composed of radiolarians (see Figure 7); (b) chaotic mass flow showing pebbles up to 0.3 meter in $\varnothing$, erodes the glass sand. The broken glass sand components at the base indicate frozen conditions during a short cold interval. Schlingmeier pit; (c) Mass flow (fanglomerate) exhibits a broad grain size spectrum without significant sorting. Predominantly composed of quartzites, lydite, acidic volcanics, and some local Keuper marlstones, some pebbles reveal thin rims possibly affected chemically (acids) or by fritting (arrows). Schlingmeier pit. 


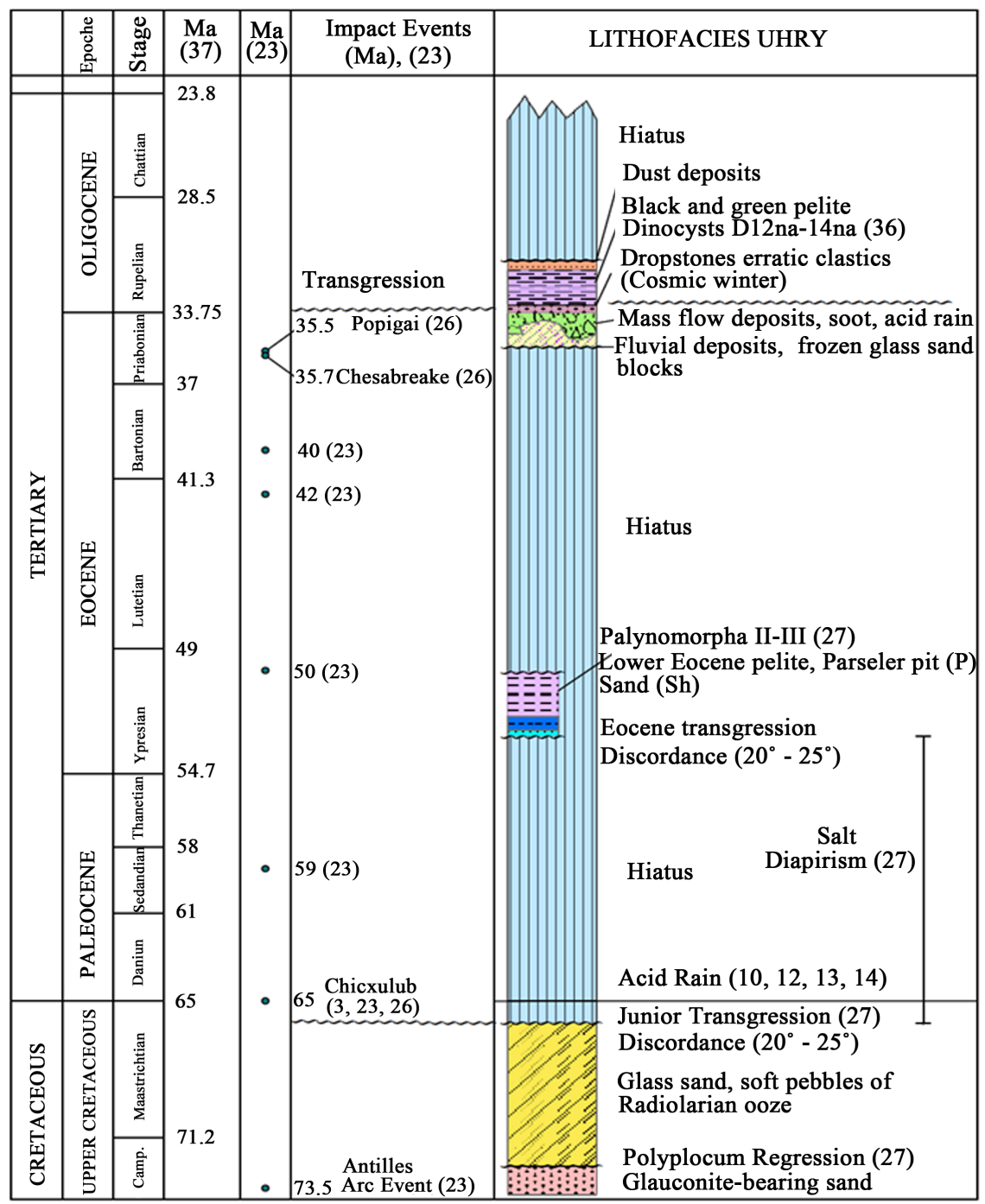

Figure 6. Biostratigraphy, major impacts, and lithology through the period from Upper Cretaceous to the Eocene/Oligocene boundary; after the Stratigraphic Table [37], major impact ages [23] [26] and Palynomorpha/Dinocyst Stratigraphy [27] [36].

The Maastrichtian age of the Uhry glass sand (=Walbeck F.) is well confirmed by a rich micro-and macro-flora of comparable occurrences at type locality Walbeck, Aller Valley Structure [27] [31].

Furthermore, white friable intra-formational pebble layers decimeter-sized in thickness, containing pebbles of centimeter-size, intercalated in the upper part of the glass sand sequence of both pits, are composed of slightly silicified radiolarian ooze of Maastrichtian age (Figure 7, [38]).

The following hiatus comprises the uppermost Maastrichtian, the complete Paleocene, and the Lower and Middle Eocene (Figure 6). Whereas, in the westerly located Parseier pit (p) mentioned above (Figure 1(a)), marine-lagoonal, glauconite-bearing Lower Eocene pelite is stratigraphically verified by Palynomorpha (Pollen Zone SP 4, Subzone SP 4a = Lower Eocene II-III) reconfirmed by Dinocysts [27]. 


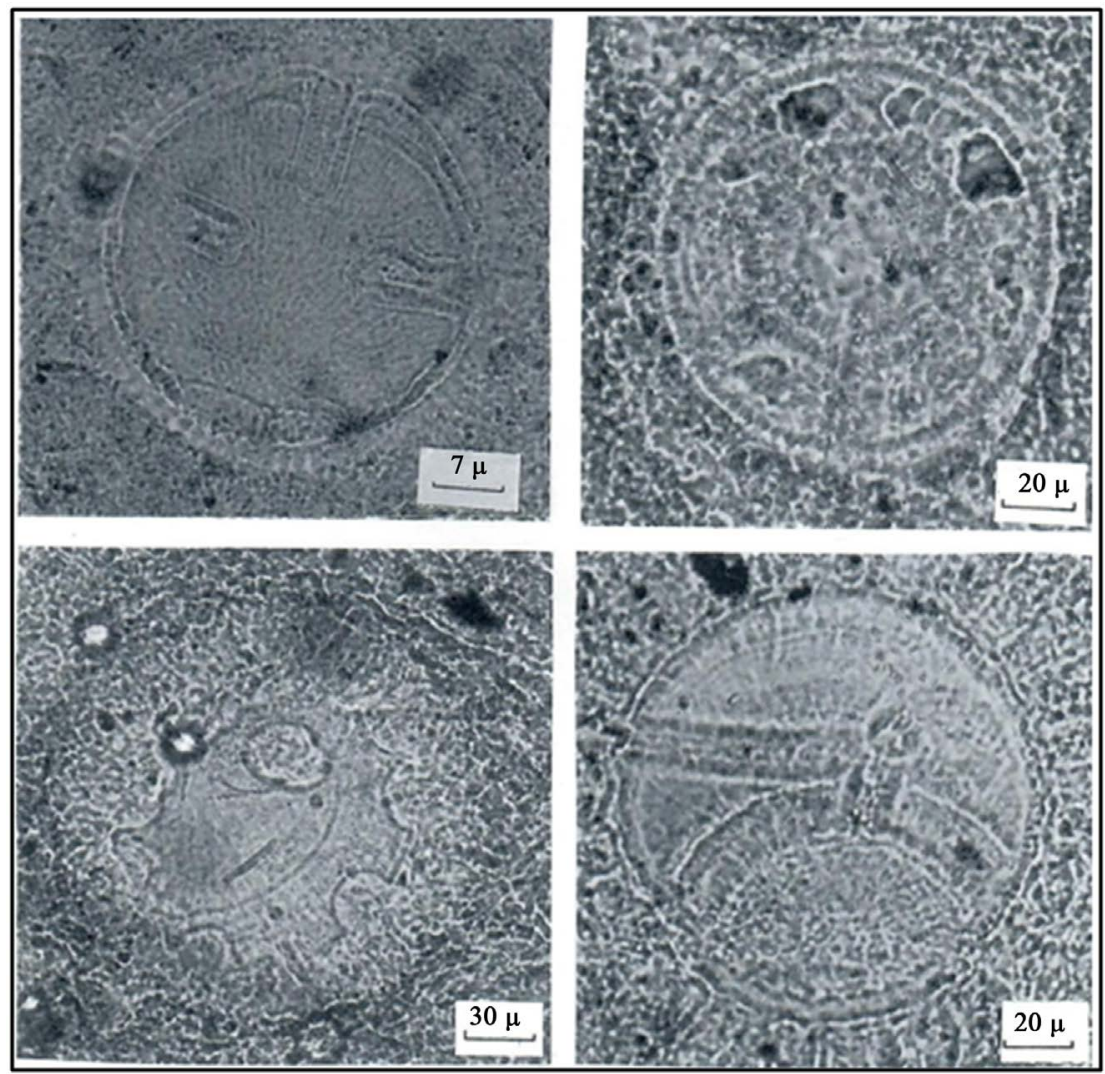

Figure 7. Maastrichtian radiolarian assemblage forming friable soft pebbles in glass sand: Suborders Acantaharia and Spumellaria [38].

Hence, the hiatus represents the $\mathrm{K} / \mathrm{T}$ event and the regional "junior transgression" both around $65 \mathrm{Ma}$ 'in age. The Lower Eocene top coincides with another "Rare Event" whichhappened around $50 \mathrm{Ma}$ ago [23].

The next hiatus includes Middle Eocene and possibly the lowermost part of Upper Eocene, whereas around the Lutetium/Bartonium b. (41.3 Ma) two other major "Rare Events" occurred $42 \mathrm{Ma}$ and $40 \mathrm{Ma}$ ago (Figure 6, [23]).

During Upper Eocene a further "Rare Event" took place around 37.2 Ma ago followed by both Popigai (35.7 Ma ago) and Cheasapeake Events (35.5 Ma ago) shortly prior to the Eocene/Oligocene b. (33.75 Ma).

The basinal coarse-grained fluvial clastics that are overlain with chaotic mass flow fill the deepest part of the main erosional channel. The top portions of the latter are characterized by erratic clastics (dropstones) of up to 0.3 meter in $\varnothing$ embedded in black pelites of up to 0.5 meter in thickness (Figure 8). The pelite age is well determined by Dinocysts whose biostratigraphic position indicates the Zones 12 na to D 14 na [36]. The co-occurrence of index marker Chiripteridium c. galea and Enneado cysta arcuata defines Subzone D 14 na, whereas Areoligeratauloma (D $12 \mathrm{na}$ - D14 nb indicates the E/O b. transition zone. All samples reveal a low number of species and individuals being, after all experience, of authochtonous origin [36]. Lack of pollen indicates vegetation-less hinterland. 

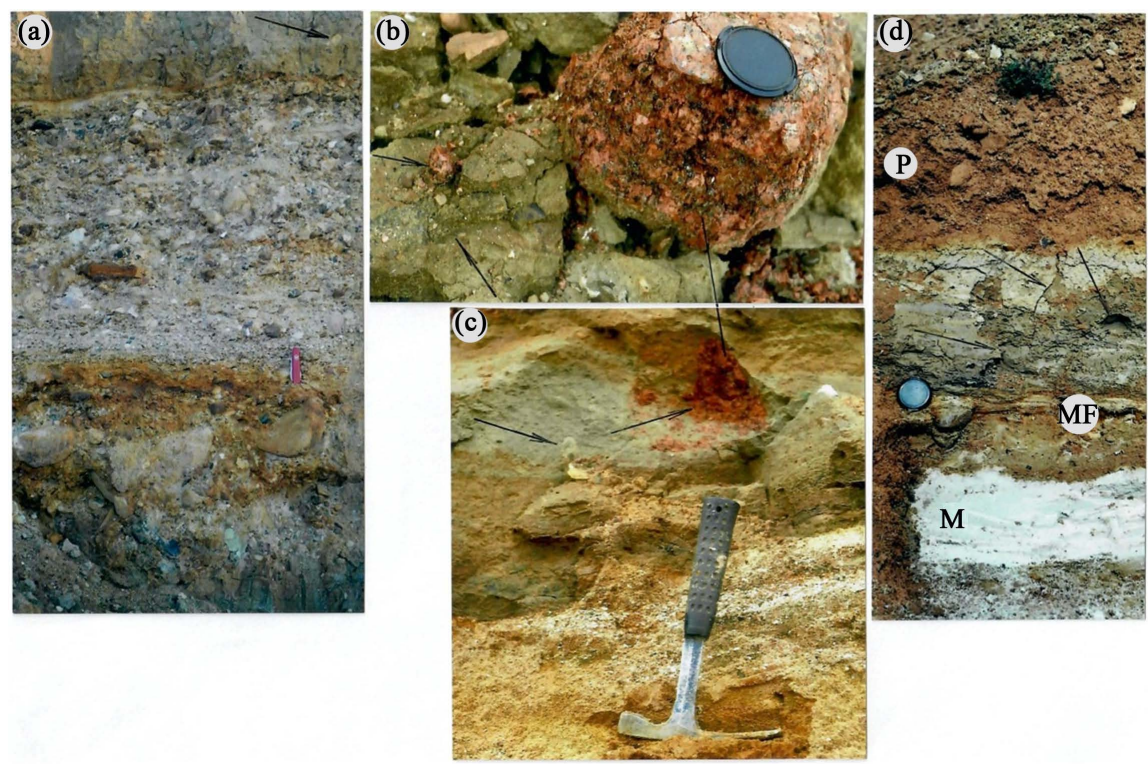

Figure 8. Erratic clastics, dropstones embedded in E/O b. pelite (see arrows). (a) Lower part: mass flow mainly composed of quartzite pebbles and regional grey-green dolomitic marlstone (Keuper), Schlingmeier pit. Middle part: fluvial reworked mass flow material Uppermost part: E/O b. pelite bearing erratic clastics embedded in a silt/clay matrix. Schlingmeier pit. Brownish colors possibly indicate depositional interruption; (b) erratic clastics and a large dropstone (syenite) embedded in E/O b. pelite. Schlingmeier pit; (c) base: Maastrichtian glass sand (M) overlain with thin mass flow relics (MF) and E/O b. pelite bearing dropstones (arrows): all covered with Pleistocene deposits (P). Ewers pit.

Thus, this dark pelite layer that changes to grey-greenish color in its top portions, incorporates the Eocene/Oligocene b. Since both Popigai E. (35.7 Ma) and Chesapeake E. (35.5 Ma) precede the E/O b. (33.9 Ma) in a short time interval (accepting the analytical error!), both clastic facies types filling the channel, coincide in age approximately with both major impacts [23] [37].

The whole sequence described from Uhry site, is wide-spread overlain with Pleistocene moraines and fluvio-glacial deposits (Elster?/Saale Glaciation) of northern provenance (Figure 2).

\section{Do the Sedimentary Formations of Uhry Site Exhibit Major Impact-Related Effects?}

\subsection{Upper Cretaceous Glass Sand (Maastrichtian = Walbeck F.)}

As sediments of an outrunning estuary system, the kaolinite-bearing clastics (missing almost completely feldspar) reveal an extremely high compositional and textural maturity [27] [38]. The significant kaolinite content may be explained by weathering processes at the top of the Variscan Basement of Middle Germany having worked since the Permian peneplaining that surface [29].

Nevertheless, it should be inferred that kaolinite neoformation by impact-initiated nitric acid ( $\mathrm{pH}-0$ ) may play an important role during heavy rainfall and flooding via dissolution of feldspar and other silicates, even through the vadose water penetrating the porous subground. This case was discussed for the 
Ordovician (Disi F.) glass sand in southern Jordan where stable tourmaline yields extreme dissolution and etching figures [39].

Meter-sized "blocks" of frozen glass sand showing angular shape were obviously dislocated along joints, gliding along a short distance to be finally embedded within the basinal fluvial clastics (Figure 9). That indicates that frozen vadose pore water consolidated the glass sand during the time around the Eocene/Oligocene b. after subtropical climate hitherto dominated Central Europe that was abruptly shocked by a cold short interval (sintwinter). Since the fluvial clastics hosting the "glass sandblocks", are younger than the angle discordance, this climatic event cannot be related to the K/T Event but certainly to the Upper Eocene major impact events.

Since the uppermost Maastrichtian and the Paleocene are missing in the section, it can be concluded that the K/T transitional sequence had been eroded since the beginning of salt diapirism [27].

\subsection{Lower Eocene Sand and Pelite}

Reworked fine-grained laminated glass sand (St in Figure 1(a)) and some 16 meter thick dark glauconite-bearing pelite (P in Figure 1(a)) of Lower Eocene, horizontally overlie the Maastrichtian glass sand with an angle unconformity $\left(20^{\circ}-25^{\circ}\right)$. Fauna, flora, and trace fossils indicate a shallow marine-lagoonal environment, possibly under sub-erosion influence by the Beinrode Salt Diapir [27]. The coastline did, probably, not extend eastward towards the investigated pits. So this unit does not show any impact-effects and therefore,it does not play any role for this subject.
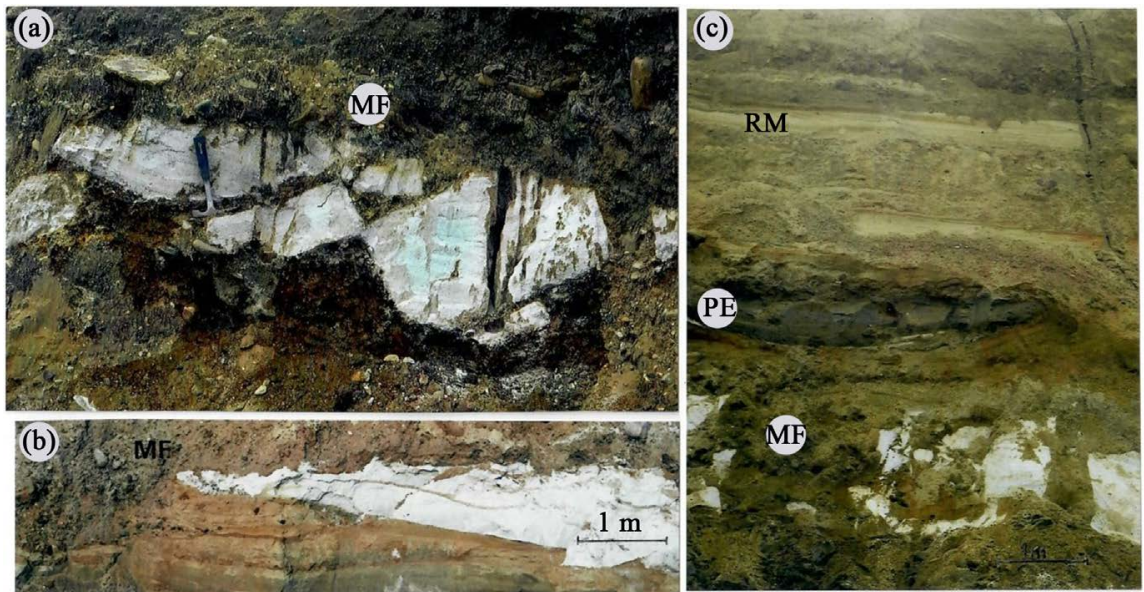

Figure 9. Frozen glass sand block broken along joints as indicators for at least one cold climate interval. (a) Broken glass sand block embedded in between basinal clastics and mass flow (MF). Schlingmeier pit; (b) meter-long glass sand block penetrated by joints filled with clastic material, also embedded in basinal clastics preceding the mass flow (MF). Ewers pit; (c) broken glass sand block penetrated by mass flow clastics (MF), overlain with dark E/O b. pelite (E/O PE). The overlying part shows fluvial clastics of unknown age with reworked glass sand (RM). Pleistocene covers the sequences. $(P)$. Schlingmeier pit. 


\subsection{Basinal Coarse-Grained Sand and High-Energetic Mass Flow of Post-Lower Eocene to Lower Oligocene}

This clastic series hitherto unknown fills as distal part of the estuary system, a northwest running channel eroding the Maastrichtian glass sand (Figure 4). The clastics overlie the angle unconformity with basinal relics of a thin $\mathrm{FeOOH}$ enriched paleosol (Figure 10). The hiatus comprises the time span from uppermost Maastrichtian to Middle Eocene (Figure 6). The fluvial clastics expose, according to Miall [40], a broad spectrum of lithofacies types (Sh, Sp, St, Sm), and host locally blocks of (former) ice-consolidated glass sand (Figure 9).

The mass flow, up to 2 meter thick, is mainly represented as massive channel fill but has generally wider regional distribution [35]. At the channel edge, vertical and even overhang-contacts to the glass sand were exposed (Figure 11). Grain size varies from clay/silt fraction up to boulders 0.5 meter in $\varnothing$, mainly exposing $\mathrm{Gm}$ and Ghlithofacies providing a chaotic sorting. The mass flow erosively overlies the basinal clastics. Predominantly, the pebbles are well rounded indicating manifold reworking and transport processes since Permian and as inventory of the later Cretaceous/Paleogene estuary system as well. Their provenance shows extreme complexity and differs significantly from that of the northern Pleistocene pebble assemblage [35].

The horse shoe-likesource areas in the southeastern/eastern hinterland are as follows:

- Ur-Saale source area [29]: Granulite, schist, Upper Carboniferous/Lower Permian granite, conglomerate, sandstone, Lower Permian volcanics, granodiorite, Halle Porphyry complex: Variscan basement, granite, porphyrite, red clastics, basalt, phonolite, kaolinite as weathering product of the former land surface (starting in Lower Permian).

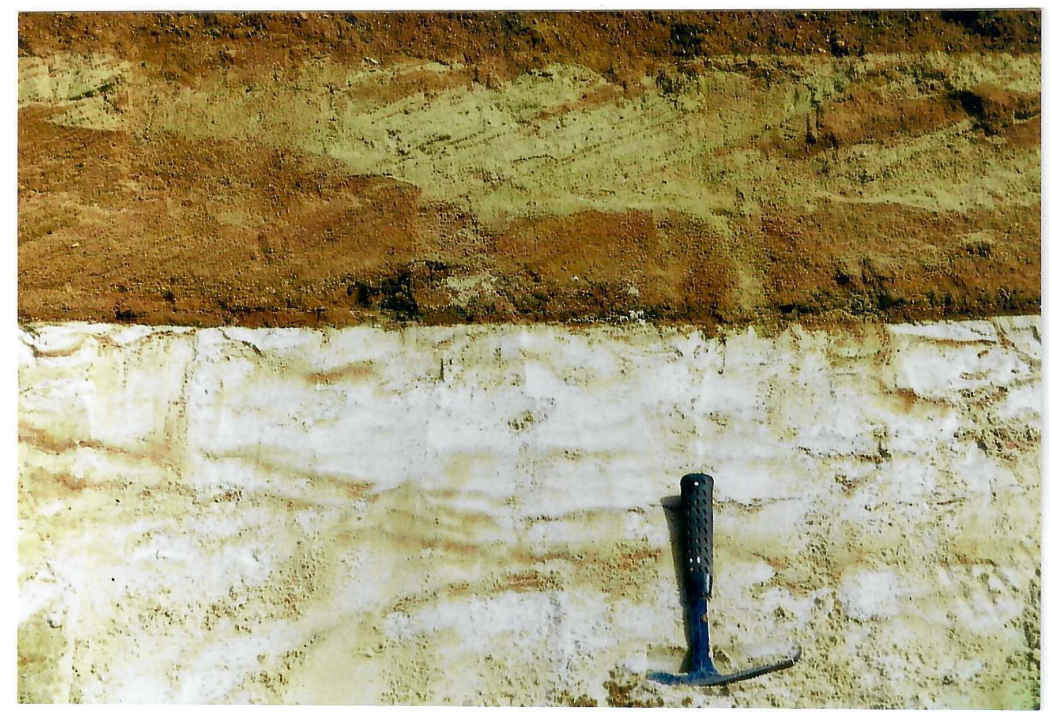

Figure 10. Maastrichtian glass sand discordantly $\left(20^{\circ}-25^{\circ}\right)$ overlain with Upper Eocene fluvial clastics (lithofacies sp). Paleosol relics at base. Northwestward transport direction. Ewers pit. 


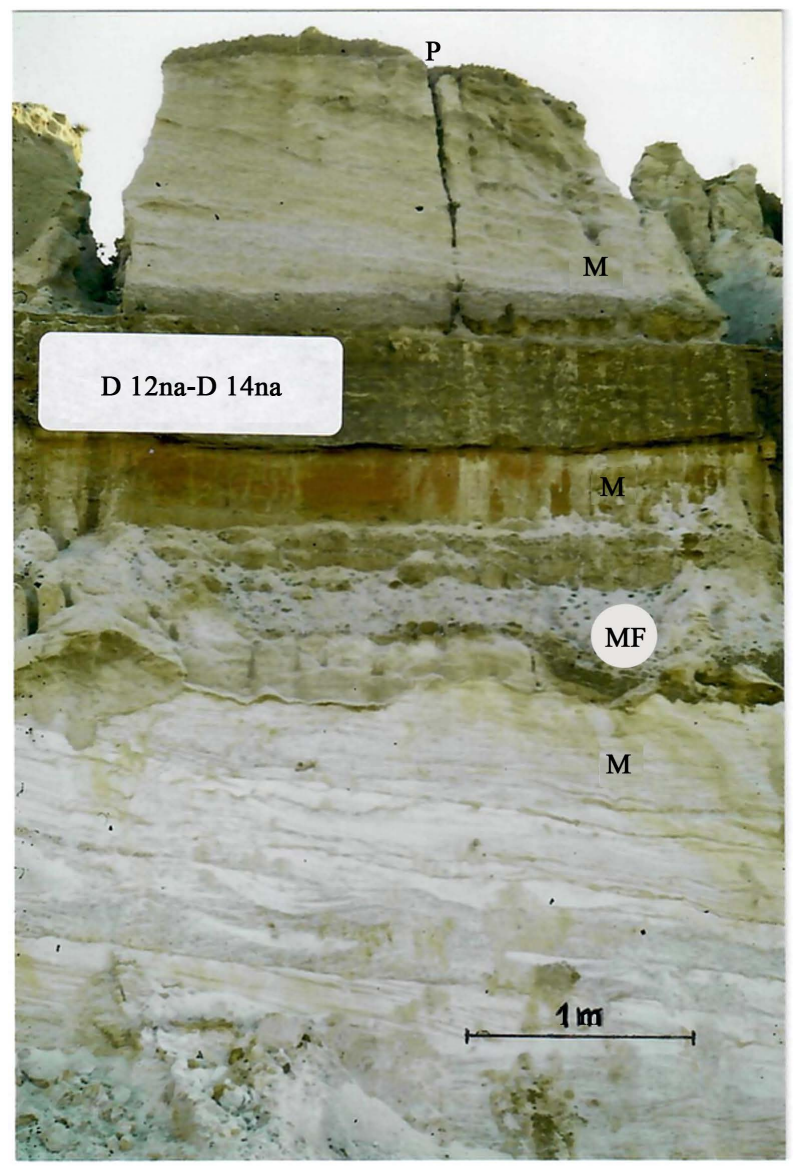

Figure 11. Maastrichtian glass sand (lithofacies types st,st,sh,sp,sl) dipping southward towards the Beienrode/Dorm Salt Diapir, is discordantly $\left(20^{\circ}-25^{\circ}\right)$ overlain with E/O b. sediments within a $10-12$ meter deep channel exhibiting a vertical, even overhanging steep wall erosional contact. The basinal clastics are missing in this section. The mass flow (MF) and the E/O b. pelite (D 12 na - D 14 na) laterally erode into the glass sand (M). Pleistocene at top. The E/O b. pelite documents approximately the level of the transgressing Rupelian sea water level. Schlingmeier pit.

- Elbe Zone: Meissen, Dresden [30]: Syenodiorite, diverse granite, quartz porphory, marine Upper Cretaceous marlstones, gneiss, red conglomerates, sandstone, porphorite, syenite.

- Harz Mts. [29]: Granite, (Brocken, Ramberg), Upper Carboniferous/Lower Permian clastics, porphyry, melaporphyre, quartzite, greywackes, diabase, lydite, dike quartz.

- Flechtingen Mt. Ridge and Elbe area [29]: Lower Carboniferous greywackes, Lower Permian red clastics, Gommern quartzite (Kulm), porphorite, quartz porphory, tuffs, along its margin: Lower and Upper Triassic.

- Aller Valley Structure [31]: Since Upper Cretaceous erosion of 1500 meter thick Mesozoic and Tertiary sedimentary rocks of the exhumed transpressional cauliflower structure.

- Local source areas provided Upper Triassic dolomitic marlstones (Keuper), Jurassic calcarenites (Lias) and Cretaceous clastics. 
Possibly, impact-related are fritted Keuper pebbles (dolomitic marlstone) covered with a thin film of soot which was reconfirmed by pit workers who occasionally find $\mathrm{C}_{\mathrm{org}}$-enrichment within the realm of the mass flow.

\subsection{Upper Eocene/Lower Oligocene Pelite and Erratic Clastics (Dropstones)}

The transitional zone mass flow/ pelite exposes clastic components up to 0.4 meter in $\varnothing$ that are separately embedded within the pelite (Figure 8). They have to be interpreted as dropstones deposited during a cold interval. Obviously the sea level rose up to the level of the main channel eroded into the glass sand, as part of the rim syncline of the Beienrode Salt Diapir during the onset of the marine transgression around the E/O b. [27] [28].

The transgressive Rupelian pelite shows two types of facies: 1) a basinal$\mathrm{C}_{\text {org }}$-enriched "black shale facies" with an illite/kaolinite signature enclosing erratic clastics, and 2) a \pm laminated grey-yellowish kaolinite-dominated facies (Figure 12, [28]). Well sorted clay/silt on top of it indicates subaerial high altitude transport [4] [5] [9] under oxidizing conditions. A red facies occasionally intercalating the pelite (Figure 13) should be a subject for Iridium analysis.

Abundant Pediastrae, especially Pediastrumkawraiskyi, the latter well known from Quaternary, hints on freshwater influence and definitely on a cold climatic

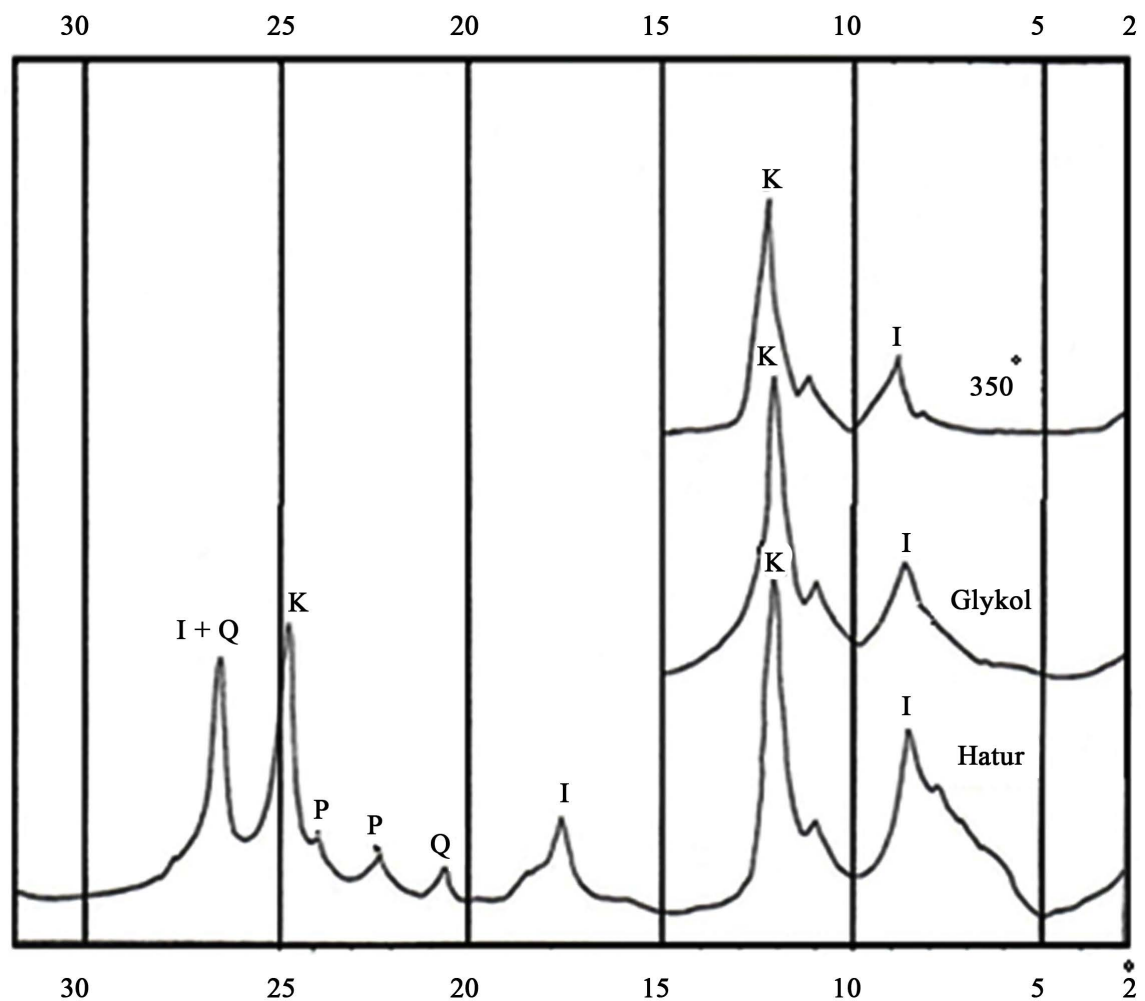

Figure 12. X-ray diffractogram of the E/O b. pelite after usual treatment. I Illite, K Kaolinite, Q Quartz P Plagioclase. Schlingmeier pit: however, localized 500 meter northeast of the site currently analyzed [58]. 


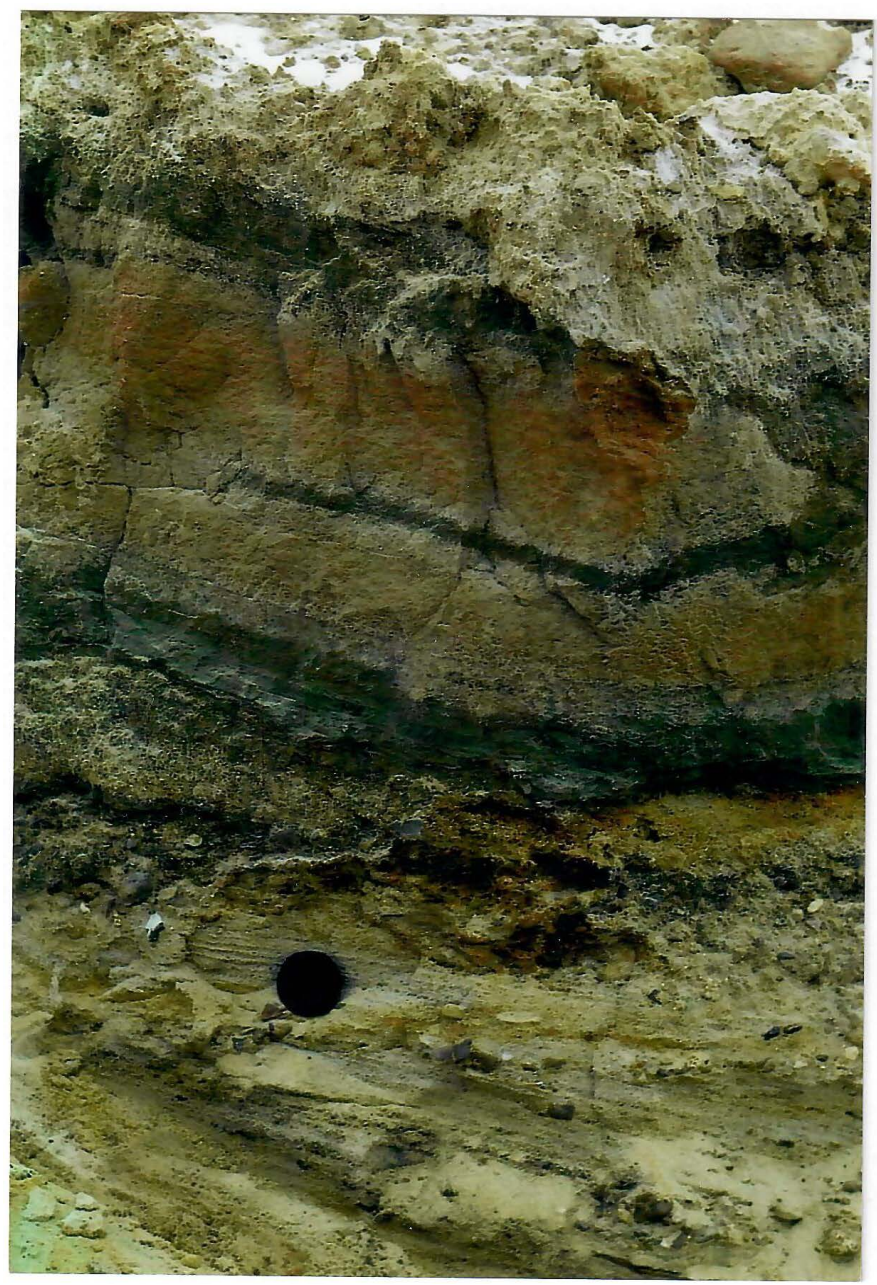

Figure 13. E/O b. pelite of varying color indicating oxidizing and reducing conditions overlying mass flow deposits (MF). Schlingmeier pit.

interval [36] for the E/O b. after a long subtropical period. Köthe [36] describes the assemblage of Dinocysts and Pediastrae as unusual. Therefore, the age of this boundary pelite coincides approximately with that of both Popigai and Cheasabreake major impacts.

The E/O b. pelite was well exposed in the Schlingmeier pit (Figure 4) during progressive glass sand exploitation and may temporarily still be encountered in the Ewers pit in the course of further exploitation, especially in its southern part.

\section{Discussion and Interpretation}

According to Figure 6 and Figure 14, there cannot be any doubt that both Popigai and Chesabreake events caused effects of worldwide extension [26].

Regarding the temporal sequence of effects during a mega-impact (Figures 15-17), the processes commence by spherical shockwave expansion into the rocks of the target area generating typical mineral and rock deformation [41] [42]. Seismic waves with $1 / 100$ of impact energy, run, around the globe within 18 hours [25]. 


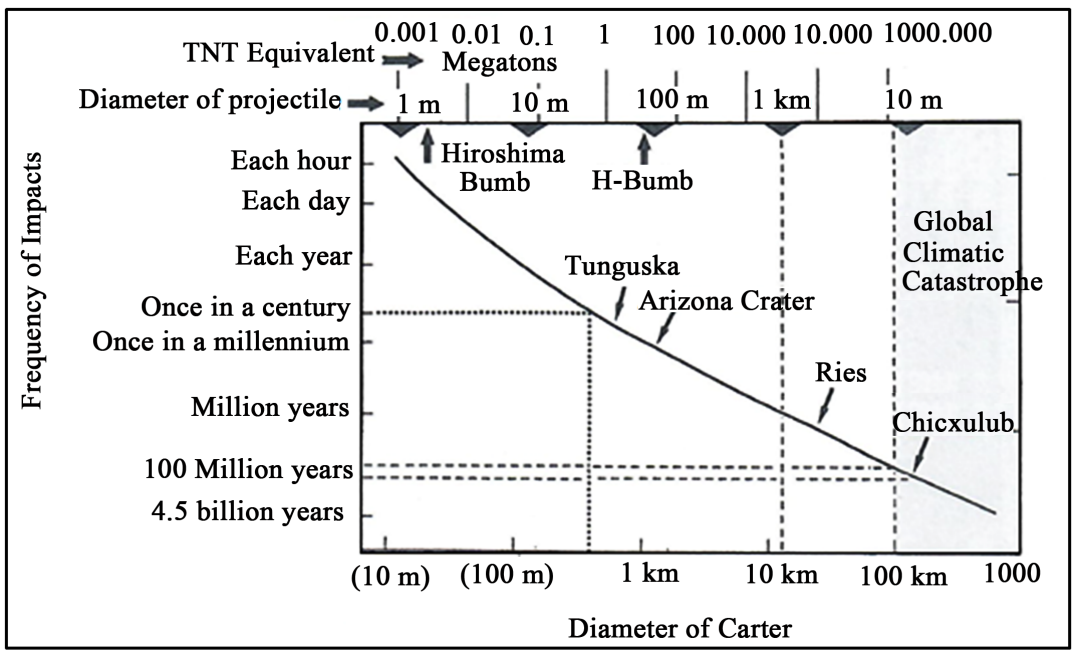

Figure 14. Frequency of impacts through earth history relating to crater, TNT-Aquivalent, bolide $\varnothing$, [26].

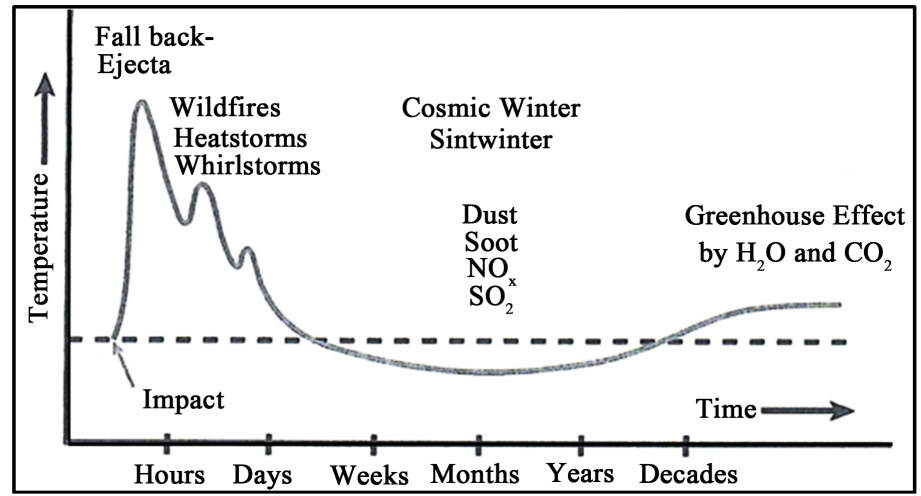

Figure 15. Relative temperature, impact products and consequences through time [26].

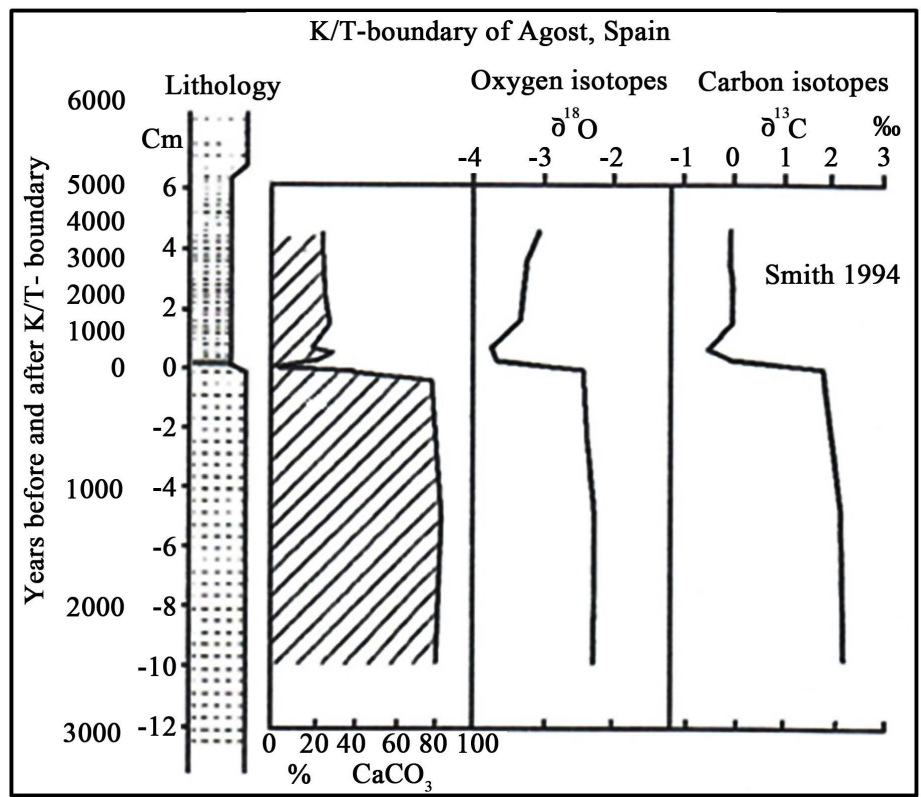

Figure 16. The K/T event from Agost, Spain and the signature of the boundary clay [26]. 


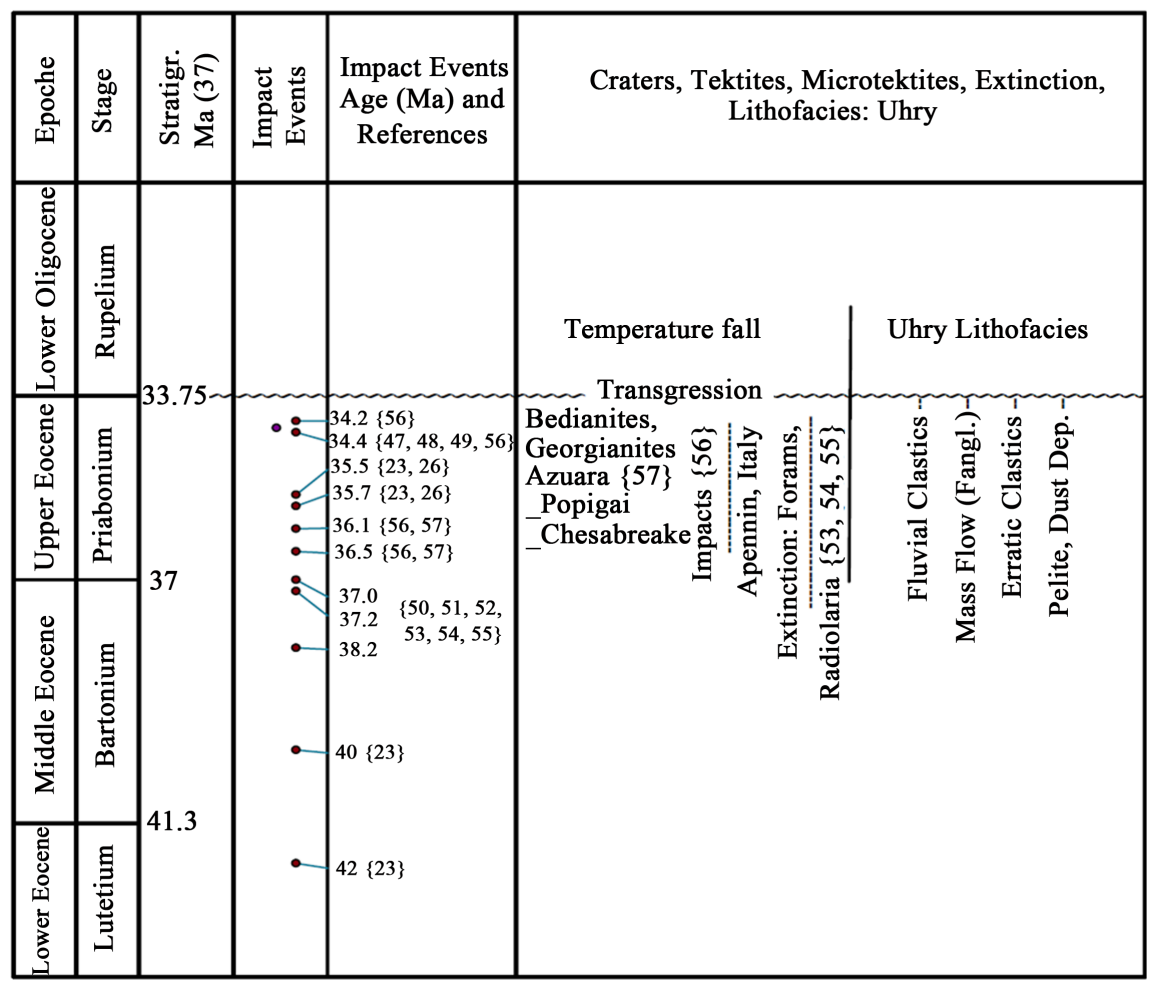

Figure 17. Impact Events and their evidence from Middle Eocene to Lower Oligocene. Stratigraphy [37], age of events [23], [26], [47]-[57].

Earthquakes re-activate faulting zones, possibly triggering volcanism, and other plate tectonic processes [23]. Thus, like the Deccan Trap Flood Basalts, India effused around the K/T b. [43], the volcanic eruptions of Middle Germany (Erzgebirge, Oberlausitz: [2] meet the E/O b. [37], and therefore might be initiated by both major impacts. Furthermore, it cannot be excluded that the K/T b. event initiated the beginning of diapirism of the Beienrode Dorm Salt structure [27].

Wildfires possibly running around the globe by generating the in-flamation of woods [4] [5], represent initial processes as verified by soot layers at the base of kaolinite boundary clay (Figure 16) and by fritted Upper Triassic dolomitic marlstones as components of the mass flow.

All these dissolution patterns relate to extreme acidity $(\mathrm{pH} \sim \mathrm{O}$ ) mainly caused by impact activation which initiates chemical reaction between the otherwise unreactive elements oxygen and nitrogen of the atmosphere to finally produce nitrous and nitric acids [14].

Furthermore, the E/O b. exhibits, in all coal pits of Middle Germany [28], the neoformation of "quartzites" possibly indicating a hiatus caused by $\mathrm{SiO} 2$ precipitation within unconsolidated sand [44].

As also discussed for the Early Paleozoic DISI F., Jordan, Arabian plate, it cannot be excluded that heavy acid rain may descend as vadose pore water into siliciclastic deposits to dissolve feldspar initiating herewith kaolinite neoformation [39] that might also be relevant for the Maastrichtian Uhry glass sand. 
The transgressive E/O b. black pelite of Uhry bearing erratic clastics (Figure 8), suffered of oxygen-deficit conditions caused by lacking photosynthesis and organic matter abundance. This seems to be important since the oxygen-deficient transgressive "black shale facies" is frequently combined with major impacts throughout the History of the Earth as verified for the early Paleozoic clastic systems of Jordan, Arabian Plate [39].

Another example for a cold interval during Lower Tertiary by erratic clastics was reported from Norway [45].

Many insiders postulate extreme heavy rain/boiling water committed during weeks/months after a major impact generating flooding of catastrophic dimension ("Deluge"), [9] [10] [11] [12] [13]. These tremendous processes leave giganticerosion features and related high energy deposits like avalanches, mass flow, block formations, fanglomerates, mostly in connection with earth quakes [15] [16] [17] [18].

Aspectacular example for such convulsive geologic processes is reported from the E/O b. at San Emigdio Range, southern California [18]: A 50 meter thick granitic breccia was deposited by a major rock slide in response to earthquakes. This "monster deposit" represents a key element in the basin architecture record.

Comparatively, as a fill of some 10 meter deep erosion channel located within the northern rim syncline of the Beienrode /Dorm Salt Structure, the mass flow of Uhry has to be interpreted as a flash flood deposit ("sturzstrom") deposited during a short process of heavy acidic/boiling rainfall which took place around the $\mathrm{E} / \mathrm{O} \mathrm{b}$. The almost complete lack of carbonate rocks, presence of reaction seams on dolomitic marlstones, and the de-carbonization of Lower Jurassic calcarenites as part of the pebble assemblage all verify the highacidity of the transport medium.

The clastics underlying the mass flow, document the beginning of increasing rainfall, as also occurred in Middle Germany, witnessed by fluvial deposits around the E/O b. [28].

The Rupelian transgression started during flash flooding. In the following time (months, yearsand even decades) gigantic volumes of ashes, dust, soot, gas and acid dominated the atmosphere and led to the adsorption of solar energy [19]. That should have initiated decrease/stop of photosynthesis and contemporaneously, the origination of "black shale facies" and mass extinction [20] [21] [22]. The latter amounts up to $39 \%$ at the $\mathrm{K} / \mathrm{T}$ b. and to $12 \%$ at the E/O b. [26].

Decrease of solar energy generates a significant fall of temperature, accompanied by heavy and long-lasting snowfall (sintwinter $=$ cosmic winter), winter ice formation, frozen vadose pore water in glass sand, erratic clastics along coastlines and in lakes, and finally darkness lasting for months, more or less to be recognized in the sedimentary record.

Temperature fall at Uhry site is reliably documented for the E/O b. (Figure 18) by: 


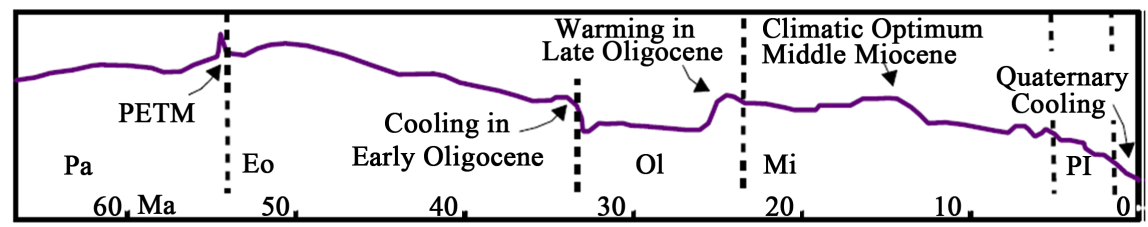

Figure 18. Temperature variation throughout Tertiary showing a significant temperature decrease at the E/O b. for a relatively long time span [59].

- Formerly frozen Maastrichtian glass sand reworked as jointed angular blocks of meter size embedded in the fluvial basinal clastics (Figure 9).

- Erratic clastics embedded in the transgressive Rupelianpelite (Figure 8).

- The Dinocyst assemblage appears as "unusual" and comprises the freshwater alga Pediastrum kawraiskyi as indicator of cold climate, hitherto only known from the Quaternary [36].

- Lack of pollen indicates vegetation-less hinterland [36].

- Macroflora-bearing Rupelianpelite deposited in Middle Germany [28], document a cool period after a long-lasting subtropical climate

Finally, the top portion of the E/O b. pelite exposes millimeter-thick dust deposits excellently sorted, to be understood as aerial transport via high altitude.

However, it should be inferred that mega-volcanism, as i.e. shown by the Toba volcano, Sumatra, Indonesia, [46], may produce similar evidence with regard to the mentioned patterns.

The scenario around the E/O b. does reveal such a high complexity of impact patterns which are additionally illustrated by (Figure 17):

- A tectite-strewn field along the eastern coast of North America (Bediasites, Georgianites) yielding an age of 34.4 Ma [47] [48] [49].

- Occurrence of microtektites in the Gulf of Mexico, Caribbian Sea, Barbados, and along the continental slope off New Jersey [50] [51] [52] where three microtektite horizons $(34.4,37,37.2,38.2 \mathrm{Ma})$ are in relation to the extinction of some foraminifera and radiolarian species [53] [54] [55].

- Studies in the North Apennins, Italy expose a series of impacts within the interval $34.2-36.5 \mathrm{Ma}[56]$

- Around the E/O b. there occurred the activation/re-activation of nappes in the Dinara, Alps and Pyrenees which can be interpreted by gravitational sliding in evaporite-bearing formations caused by impact impulse [24]. Very probably related to the re-activation of nappes/sliding rock formations at Murillo de Galego, Pyrenees, a crater of $35-40 \mathrm{Km}$ in $\varnothing$ was discovered at Azuara , in the southern foreland of the Pyrenees south of Zaragossa, generated around the E/O b./Lower Oligocene. High pressure and high temperature mineral phases indicate a major impact [57] [58].

- A recent publication by Schellnhuber [59] includes a temperature curve throughout Tertiary. There appears an abrupt temperature fall at the E/O b. that may allow concluding the interdependence with the impact events which took place throughout Upper Eocene. High concentrations of ash, gas, soot, and dust having probably remained in the atmosphere/stratosphere for a 
longer time span (centuries or even more) would have caused "cosmic winter" conditions (comp. [19]).

\section{Conclusions}

The period lasting from the $\mathrm{K} / \mathrm{T} \mathrm{b}$. to the $\mathrm{E} / \mathrm{O} \mathrm{b}$. yields a relatively high number of impact events (including tektites/micro-tektites), with their age mostly close to that of biostratigraphic boundaries (Figure 6 and Figure 17).

The similar age difference between both methods ( $1 \mathrm{Ma}$ ) may be a subject of analytical error discussion, where the biostratigraphic boundary mostly follows the related impact age. The astonishing high coincidence of both does obviously not indicate a lucky chance, and therefore infers that the impact events had significant influence on the fauna and flora revealing a species loss of $12 \%$ at the $\mathrm{E} / \mathrm{O} \mathrm{b}$

However, the coincidence of commencing diapirism of the Beienrode/Dorm Salt Structure with the K/T b. as well as rising volcanism in Middle Germany at the E/O b. could be a lucky chance, but cannot be excluded as impact-related phenomenon.

The manifold co-evidence of transgressive "black shale facies" throughout the Earth History with convulsive erosional and depositional processes, missing carbonate, kaolinite predominance, several cold climate indicators around the E/O b., leave no doubt that both Popigai and Chesabreake events, and very probably others, had, together with tektites/micro-tektites, global influence on the E/O b. sediments including Uhry site.

\section{Closing Statement}

It is merely a question of time to encounter more effects of major impacts globally distributed around formation boundaries throughout the Earth History, keeping in mind Price's concept. However, it should be stressed that megavolcanoes and hot spot-directed Trapp basalt effusions may generate similar effects except Iridium anomalies and tektites, and that in connection with synchronous mass extinction (See also studies on the Early Paleozoic System of Jordan [39]).

Thus, Uhry site just reconfirms that, by the interplay of cosmic and terrestrial processes, Earth on the whole is sensitively concerned.

\section{Acknowledgements}

Many thanks are addressed to Dr. A. Köthe for the micropaleontological analysis of the E/O b. pelites and to Prof. Dr. H.-G. Röhling for facilitating the analyses, both from the Bundesanstaltfür Geowissenschaften und Rohstoffe, Hannover. We are gratefulfoe access to both pits throughout $\sim 40$ years.

\section{References}

[1] Müller, A.M.K. (1981) Interdisziplinäre Forschung als Geschichtliche Herausforderung. 
Pressestelle der Universität Hamburg, Hamburg, 37-45.

[2] Clifton, H.E. (1988) Sedimentologic Relevance of Convulsive Geologic Events. In: Geological Society of America Special Papers, Vol. 229, 1-6.

[3] Alvarez, L., Alvaresz, W., Asaro, F. and Michel, H.V. (1980) Extraterrestrial Cause for the Cretaceous/Tertiary Extinction. Science, 208, 1095-1108. https://doi.org/10.1126/science.208.4448.1095

[4] Wolbach, W.S., Lewis, R.S. and Anders, E. (1985) Cretaceous Extinctions: Evidence for Wildfires and Search for Meteoric Material. Science, 230, 167-170.

https://doi.org/10.1126/science.230.4722.167

[5] Hsü, K.J. (1988) Cretaceous/Tertiary Boundary Sediments. In: Clifton, H.E., Ed., Sedimentological Relevance of Convulsive Geologic Events, Geological Society of America Special Papers, Vol. 229, 143-154.

[6] Wolbach, W.S., Gilmour, I., et al. (1990) Major Wildfires at the Creataceous/ Tertiary Boundary. In: Geological Society of America Special Papers, Vol. 247, 391-400.

[7] Melosh, H.J., Schneider, N.M., Zahnle, K.J. and Latham, D. (1990) Ignition of Global Wildfires of the Cretaceous/Tertiary Boundary. Nature, 343, 251-254. https://doi.org/10.1038/343251a0

[8] Glass, B.P. (1990) Tektites and Mikrotektites: Key Facts and Interference. Tectonophysics, 171, 393-404. https://doi.org/10.1016/0040-1951(90)90112-L

[9] Pollack, J.B., Toon, O.B., Ackerman, T.P., McKay, C.P. and Turco, R.P. (1983) Environmental Effects of an Impact-Generated Dust Cloud: Implications for the Cretaceous/Tertiary Extinction. Science, 219, 287-289.

https://doi.org/10.1126/science.219.4582.287

[10] Prinn, R.G. and Fegley, B. (1987) Bolide Impacts, Acid Rain, and Biospheric Traumas at the Cretaceous/Tertiary Boundary. Earth and Planetary Science Letters, 83, 1-15. https://doi.org/10.1016/0012-821X(87)90046-X

[11] Croft, S.K. (1982) A First Order Estimate of Shock Heating and Vaporization in Oceanic Impacts. In: Geological Society of America Special Papers, Vol. 190, 143-152. https://doi.org/10.1130/SPE190-p143

[12] Crutzen, P.J. (1987) Acid Rain at the K/T Boundary. Nature, 330, 108-109. https://doi.org/10.1038/330108a0

[13] Zahnle, K.J. (1990) Atmospheric Chemistry by Large Impacts. In: Geological Society of America Special Papers, Vol. 247, 271-288.

[14] Koch, H.P. (2000) The Diluvian Impact. Peter Lang, Europ. Verlag der Wissensch, Wien, New York, $274 \mathrm{p}$.

[15] Pilkey, O.H. (1988) Giant Sedimentation Events. In: Clifton, H.E., Ed., Sedimentologic Relevance of Convulsive Geologic Events, Geological Society of America Special Papers, Vol. 229, 93-100.

[16] Moore, G.W. and Moore, J.G. (1988) Large-Scale Bedforms in Boulder, Gravel Produced by Giant Waves in Hawai. In: Clifton, H.E., Ed., Sedimentologic Relevance of Convulsive Geologic Events, Geological Society of America Special Papers, Vol. 229, 101-110.

[17] Fraser, G.S. and Bleuer, N.K. (1988) Sedimentologic Consequences of Two Floods of Extreme Magnitude in the Late Wisconsinian Wabash Valley. In: Clifton, H.E., Ed., Sedimentologic Relevance of Convulsive Geologic Events, Geological Society of America Special Papers, Vol. 229, 111-126.

[18] DeCelles, P.G. (1988) Deposits of a Middle Tertiary Convulsive Geologic Event, San 
Emigdio Range, Southern California. In: Clifton, H.E., Ed., Sedimentologic Relevance of Convulsive Geologic Events, Geological Society of America Special Papers, Vol. 229, 127-142.

[19] Clube, S.V.M. and Napier, W.M. (1990) The Cosmic Winter. Black well, Oxford.

[20] Sheehan, P.M. and Russel, D.A. (1994) Faunal Change Following the Cretaceous-Tertiary Impact: Using Paleontological Data to Assess the Hazards of Impacts. In: Gehrels, T., Ed., Hazards due to Comets and Asteroids, University of Arizona Press, Tucson, AZ, 879-893.

[21] Solan, R.E., Rigby Jr., J.K., van Valen, L.M. and Gabriel, D. (1986) Gradual Dinosaur Extinction and Simultaneous Ungulate Radiation in the Hell Creek Formation. Science, 232, 629-633.

[22] Rampino, M.R. and Stothers, R.B. (1984) Terrestrial Mass Extinction, Cometary Impacts, and the Sun's Motion Perpendicular to the Galactic Plane. Nature, 308, 709-712. https://doi.org/10.1038/308709a0

[23] Price, N.J. (2001) Major Impacts and Plate Tectonics. Routledge, London, 324 p.

[24] Tollmann A. and E. (1993) Und die Sintflut gab es doch. Vom Mythos zur Historischen Wirklichkeit, Droemer Knaur, München, 560 p.

[25] Clube, S.V.M. and Napier, W.M. (1986) Giant Comets and the Galaxy: Implications of the Terrestrial Record. In: Smoluchowsky, J.N., et al., Eds., The Galaxy and Solar System, University of Arizona Press, Tucson, AZ, 260-285.

[26] Stöffler, D. (2003) Bedrohung aus dem Weltall. Asteroiden und Kometen. In: Emmermann, R., Ed., An den Fronten der Forschung, Verhandlungen der Gesellschaft Deutscher Naturforscher und Ärzte, 22. Vers., Halle, 81-98.

[27] Niebuhr, B. and Ernst, G. (1991) Faziesgeschichte und Entwicklungsdynamik von Campan, Maastricht und Eozän im Beienroder Becken (E-Niedersachsen). Zeitschrift der Deutschen Geologischen Gesellschaft, 142, 251-283.

[28] Standke, G. (2008) Paläogeografie des Älteren Tertiärs (Paläozän-Untermiozän) im Mitteldeutschen Raum. Zeitschrift der Deutschen Gesellschaft für Geowissenschaften, 159, 1, 81-104.

[29] Wagenbreth, O. and Steiner, W. (1990) Geologische Streifzüge. Landschaft und Erdgeschichte zwischen Kap Arkona und Fichtelberg. Deutscher. Verlag für Grundstoffindustrie, Leipzig, 204 p.

[30] Mattern, F. (1996) The Elbe Zone at Dresden: A Late Paleozoic Pull-Apart Intruded Shear Zone. Zeitschrifl der Deutschen Geologische Gesellschaft, 147, 57-80.

[31] Best, G. and Zirngast, M. (2002) Die Strukturelle Entwicklung der Exhumierten Salzstruktur “Oberes Allertal”. Bundesanstalt F. Geowiss. und Rohstoffe, Hannover, $109 \mathrm{p}$.

[32] Kockel, F. (1991) Die Strukturen im Untergrund des Braunschweiger Landes. Geologisches Jahrbuch $A, 127,391-404$.

[33] Stänicke, J. (1979 ) Kartierung auf Bl. Stüpplingen (Nr.3731), Dipl.-Karierung, TU Braunschweig, Geol. Karte 1:10000, 56 p.

[34] Probst, U. (1980) Dipl-Kartierung im NW-Teil des Messtischbl.Stüpplingen (Nr.3731), TU Braunschweig Geol. Karte 1:10000, 56 p.

[35] Look, E.-R. (1985) Geologie, Bergbau und Urgeschichte im Braunschweiger Land. Geologisches Jahrbuch A, 88, 452 p.

[36] Köthe, A. (2007) Mikropaläontologischer Untersuchungsbericht, Projekt Glassandgrube Uhry, Laborproben Nr. P 75011-P 75014, Pa Strata Nr. 1597-2637, Lan- 
desamt für Bergbau, Energie und Geologie, Referat 3.9, 2 p, Hannover.

[37] Deutsche Stratigraphische Kommission (DSK), Stratigraphische Tabelle von Deutschland, 2002, Stein, Potsdam, mit Beiheft.

[38] Ramme, G. (1982) Sedimentologische Untersuchungen an Tertiären Sanden (meanwhile changed: Maastrichtian) im Bereich des Dorm. Dipl-Thesis, TU Braunschweig, $138 \mathrm{p}$, and additional report on glass sand (unpubl).

[39] Schneider, W. and Salameh, E. (2012) Did Major Impact Affect Sedimentologic/Sequence-Analytical Patterns of the Early Paleozoic Sedimentary Systems of Jordan, Arabian Plate? Open Journal of Geology, 2, 241-252.

https://doi.org/10.4236/ojg.2012.24024

[40] Miall, A.D. (1996) The Geology of Fluvial Deposits. Springer, Berlin, 582 p.

[41] Stöffler, D. and Grieve, R.A.F. (1994) Classification and Nomenclature of Impactmetamorphic Rocks: A Proposal to the IUGS Subcommission on the Systematic of Metamorphic Rocks. In: Montanari, A. and Smit, J., Eds., European Science Foundation Scientific Network on Impact Cratering and Evolution of Planet Earth, Östersund Workshop, Post Östersund Newsletter, 9-15.

[42] Reimold, W.U. (2007) Revolutions in the Earth Sciences: Continental Drift, Impact and Other Catastrophes. South African Journal of Geology, 110, 1-46. https://doi.org/10.2113/gssajg.110.1.1

[43] Negi, J., et al. (1993) A Possible K/T Boundary Bolide Impact Site Offshore Bombay and Triggering of Rapid Deccan Volcanism. Physics of the Earth and Planetary Interiors, 76, 189-197. https://doi.org/10.1016/0031-9201(93)90011-W

[44] Krauskopf, K.B. (1982) Introduction to Geochemistry. 2nd Edition, McGraw-Hill Company, London, Paris, 617 p.

[45] Dalland, A. (1977) Erratic Clastic in the Lower Tertiary Deposits of Svalbard. Evidence of transport by Winter Ice. Arbok Norsk Polar Institute, Oslo, 151-165.

[46] Rampino, M.R. and Ambrose, S.H. (2000) Volcanic Winter in Garden of Eden: The Toba Supereruption and the Late Pleistocene Human Population Crash. In: McCoy, R.W. and Heiken, G., Eds., Volcanic Hazards and Disaster in Human Antiquity, Geol Soc Amer Spec Pap, 345: 71-82

[47] Barnes, V.E. (1963) Tektite Strewn-Fields. In: O’keefe, A., Ed., Tektites, University of Chicago Press, Chicago, IL, 25-50.

[48] Barnes, V.E. (1989) Comets and the Origin of Tektites. Abstr. 52 and Annual Meeting, Meteoritics Society, Vienna, p. 10.

[49] Glass, B.P., Swincki, M.B. and Zwart, P.A. (1979) Australasian, Ivory Coast and North American Tektite Strewnfields-Size, Mass and Correlation with Geomagnetic Reversals and Other Earth Events. Proceedings of the 10 th Lunar and Planetary Science Conference, Houston, TX, 19-23 March 1979, 2535-2545.

[50] Glass, B.P. (1988) Late Eocene Impact Events Recorded in Deep-Sea Sediments. Global Catastrophes in Earth History: An Interdisciplinary Conference on Impacts, Volcanism, and Mass Mortality, 63-64.

[51] French, B.M. (1998) Traces of Catastrophe: A Handbook of Shock-Metamorphic Effects in Terrestrial Meteoritic Impact Structures. LPI Contribution No. 945. Lunar and Planetary Institute, Houston, 120 p.

[52] Glass, B.P. (1992) Impact Ejects Associated with the Australian and North American Microtektite Layers. Abstracts of the Lunar and Planetary Science Conference, 23,415 . 
[53] Alvarez, W., Asaro, F., Michel, H.V. and Alvarez, L.W. (1982) Iridium Anomaly Approximately Synchronous with Terminal Eocene Extinctions. Science, 216, 886-888. https://doi.org/10.1126/science.216.4548.886

[54] Ganapathy, R. (1982) Evidence for a Major Impact on Earth 34 Million Years Ago: Implication for Eocene Extinctions. Science, 216, 885-886.

https://doi.org/10.1126/science.216.4548.885

[55] Keller, G. (1986) Stepwise Mass Extinctions and Impact Events: Late Eocene to Early Oligocene. Marine Micropaleontology, 10, 267-293. https://doi.org/10.1016/0377-8398(86)90032-0

[56] Montanari, A. (1990) Geochronology of the Terminal Eocene Impacts. In: Geological Society of America Special Papers, Vol. 247, 607-616.

[57] Ernstson, K. and Fiebag, J. (1992) The Azuara Impact Structure (Spain): New Insights from Geophysical and Geological Investigations.Geol. Geologische Rundschau, 81, 403-427. https://doi.org/10.1007/BF01828607

[58] Freiberg, H.-J. (1981) Sedimentologische Untersuchungen an Sedimenten des Helmstedter Tertiärs. Dipl. Thesis, TU Braunschweig, Braunschweig, 106 p.

[59] Schellnhuber, H.J. (2015) Selbstverbrennung. Die fatale Dreiecksbeziehung zwischen Klima, Mensch und Kohlenstoff. C. Bertelsmann, München, 778 p. 